\title{
SUPPORTED ORGANOMETALLIC COMPLEXES. SURFACE CHEMISTRY, SPECTROSCOPY, AND CATALYSIS
}

Progress Report

for Period September 15, 1992 - November 14, 1993

Tobin J. Marks

Department of Chemistry

Northwestern University

Evanston, IL 60208-3113

April 1993

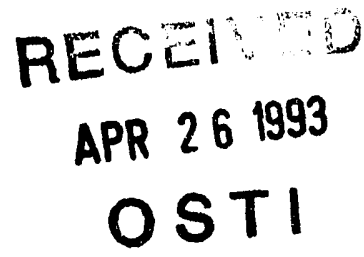

NOT I C E

This report was prepared as an account of work sponsored by the United States Government. Neither the United States nor the Department of Energy, nor any of their employees, nor any of their contractors, subcontractors, or their employees, makes any warranty, express or implied, or assumes any legal liability or responsibility for the accuracy, completeness, or usefulness of any information, apparatus, product or process disclosed or represents that its use would not infringe privately-owned rights.

Prepared for

THE U.S. DEPARTMENT OF ENERGY AGREEMENT NO. DE-FG02-86ER13511 
ABSTRACT

The long-range goal of this project is to elucidate and understand the surface chemistry and catalytic properties of well-defined, highly-reactive organometallic molecules (principally based upon abundant actinide, lanthanide, and early transition elements) adsorbed on metal oxides and halides. The nature of the adsorbed species is probed by a battery of chemical and physicochemical techniques, to understand the nature of the molecule-surface coordination chemistry and how this can give rise to extremely high catalytic activity. A complementary objective is to delineate the scope and mechanisms of the heterogeneous catalytic reactions, as well as to relate them both conceptually and functionally to model systems generated in solution.

\section{DISCLAIMER}

This report was prepared as an account of work sponsored by an agency of the United States Government. Neither the United States Government nor any agency thereof, nor any of their employees, makes any warranty, express or implied, or assumes any legal liability or responsibility for the accuracy, completeness, or usefulness of any information, apparatus, product, or process disclosed, or represents that its use would not infringe privately owned rights. Reference herein to any specific commercial product, process, or service by trade name, trademark, manufacturer, or otherwise does not necessarily constitute or imply its endorsement, recommendation, or favoring by the United States Government or any agency thereof. The views and opinions of authors expressed herein do not necessarily state or reflect those of the United States Government or any agency thereof. 


\section{INTRODUCTION}

Many important transformations in heterogeneous catalysis involve the creation or modification of surface-bound metal-hydrocarbyl (alkyl, aryl, etc.) functionalities. An attractive approach to understanding the properties of such highly reactive species is to create them by the adsorption of well-defined molecular precursors onto carefully prepared surfaces. For several classes of early transition metal hydrocarbyls, it has been known since the 1960's that adsorption on high surface area metal oxides is accompanied by dramatic but poorly understood enhancements in activity for olefin transformations such as polymerization and metathesis. The study of such materials is of both fundamental scientific significance (What unique surface coordination chemistries give rise to such enhancements in chemical reactivity?) as well as technological interest (What clues are offered regarding the nature of highly efficient current generation heterogeneous and homogeneous olefin polymerization catalysts? Is it possible to "tailor" catalysts with improved chemo-, regio-, and stereoselectivity?). Despite these motivations and considerable empirical data, it is fair to say that our understanding of the overall surface coordination chemistry as well as the precise nature of the catalytically active sites has been at a very primitive level. There is clearly a need for more chemical/structural information, acquired under carefully controlled conditions and connected to current day molecular organometallic phenomenology via functional solution phase models.

Efforts at Northwestern to characterize such molecule-surface interactions have focused on characterizing the species found when selected actinide and group 4 alkyls are adsorbed on surfaces such as dehydroxylated or partially dehydroxylated $\mathrm{Al}_{2} \mathrm{O}_{3}, \mathrm{MgCl}_{2}, \mathrm{MgO}, \mathrm{SiO}_{2}$, etc. Characterization tools have ranged from product analysis (What gaseous products are evolved upon adsorption? How are isotopic labels distributed?), to catalytic analysis (kinetics and rate law, regiochemistry, isotopic labelling, poisoning to determine \% of active sites), to stoichiometric probes (reagents selective for surface hydride or hydrocarbyl functionalities), to spectroscopic methods (CPMAS and MAS NMR, XPS, UV-VIS, FT-IR, EPR). Since many of these adsorbate centers have high catalytic activities for certain olefin transformations (vide infra), the nature of the adsorbate centers becomes particularly 
3

intriguing. Closely connected to the surface studies have been efforts to model the proposed active sites in homogeneous solution. These latter investigations have been fruitful, and the products additionally offer an attractive means of understanding several important yet elusive classes of homogeneous catalysts. Thus, we see the combined heterogeneous /homogeneous research activities as being highly symbiotic, with the former teaching us new things about homogeneous catalysis, and vice versa.

\section{RESEARCH ACCOMPLISHED DURING THE PAST YEAR UNDER DOE SUPPORT}

The long-range goal of our program is to quantitatively define those modes of interaction that take place between organometallic molecules and inorganic surfaces and, ultimately, to correlate various molecule-surface structures with, and to model, catalytic properties.

\section{A. Organoactinide Surface Chemistry and Heterogeneous Catalysis.}

A detailed kinetic and mechanistic study of arene hydrogenation by the supported organoactinide complexes $\mathrm{Cp}^{\prime \prime T h}\left(\right.$ benzyl) $3 / \mathrm{DA}(1 / \mathrm{DA}), \operatorname{Th}\left(1,3,5-\mathrm{CH}_{2} \mathrm{C}_{6} \mathrm{H}_{3} \mathrm{Me}_{2}\right)_{4} / \mathrm{DA}(2 / \mathrm{DA})$, and $\operatorname{Th}\left(\eta^{3}\right.$-allyl) $/ \mathrm{DA}$ $(3 / \mathrm{DA})$ where $\mathrm{Cp}^{\prime}=\eta^{5}-\mathrm{Me}_{5} \mathrm{C}_{5}$ and $\mathrm{DA}=$ dehydroxylated $\gamma$-alumina. In slurry reactions $\left(90^{\circ} \mathrm{C}, \mathrm{P}_{\mathrm{H}_{2}}=\right.$ $180 \mathrm{psi}$ ), the activity for benzene hydrogenation follows the order $1 / \mathrm{DA}<2 / \mathrm{DA}<3 / \mathrm{DA}$ with $N_{t}$ for $3 / \mathrm{DA}$ $\approx 25,000 \mathrm{~h}^{-1}$ active site. ${ }^{-1}$ This approaches or exceeds most conventional platinum metal catalysts in efficacy for benzene reduction (Table 1). Benzene hydrogenation by $3 / \mathrm{DA}$ at $90^{\circ} \mathrm{C}, \mathrm{P}_{\mathrm{H}_{2}}=180 \mathrm{psi}$ follows the rate law $N_{t}=v$ [benzene $]^{\circ}\left[P_{H_{2}}\right]^{1}$ with $N_{t}\left(H_{2}\right) / N_{t}\left(D_{2}\right)=3.5 \pm 0.3$ and $E_{a}=16.7 \pm 0.3$ kcal mol..$^{-1}$ Partially hydrogenated products cannot be detected at partial conversions, and there is no $D_{2}$ incorporated in the unconverted benzene. $D_{2}$ is not delivered to a single benzene face, but rather $a 1: 3$ mixture of all-cis and cis, cis, trans, cis, trans isotopomers is formed. Active site characterizations using $\mathrm{D}_{2} \mathrm{O}$ poisoning, hydrogenolysis, and $\mathrm{CH}_{3} \mathrm{Cl}$ dosing indicate that $\leq 8 \pm 1 \%$ of the Th surface sites are responsible for the bulk of the benzene hydrogenation. EPR and XPS studies provide no evidence for surface Th oxidation states less than +4 . As a function of arene, the relative rates of $\operatorname{Th}\left(\eta^{3}\right.$ $\left.\mathrm{C}_{3} \mathrm{H}_{5}\right)_{4}$ /DA-catalyzed hydrogenation are benzene $>$ toluene $>p$-xylene $>$ naphthalene, with the regiochemistry of $p$-xylene reduction similar to that for benzene. Experiments with 1:1 benzene: $p$-xylene 
Table I . Product and Kinetic Data for the Th $\left(\eta^{3}-\mathrm{C}_{3} \mathrm{H}_{5}\right)_{4} / \mathrm{DA}-$ Catalyzed Hydrogenation of Various Arenes".

\section{Substrate}

Product

$\mathbf{N}_{\mathbf{t}}\left(\mathrm{s}^{-1} \pm 1.5 \%\right)$

$\mathrm{C}_{6} \mathrm{H}_{6}$

$\mathrm{C}_{6} \mathrm{H}_{12}$

$6.85^{b}$

$\mathrm{C}_{6} \mathrm{D}_{6}$

$\mathrm{C}_{6} \mathrm{H}_{6} \mathrm{D}_{6}$

$6.78^{\mathrm{b}}$

$\mathrm{CH}_{3} \mathrm{C}_{6} \mathrm{H}_{5}$

$\mathrm{CH}_{3} \mathrm{C}_{6} \mathrm{H}_{11}$

$4.10^{\mathrm{b}}$

$\mathrm{CD}_{3} \mathrm{C}_{6} \mathrm{D}_{5}$

$\mathrm{CD}_{3-x} \mathrm{H}_{\mathrm{x}} \mathrm{C}_{6} \mathrm{H}_{11}$

$4.00^{\mathrm{b}}$

$1,4-\mathrm{CH}_{3} \mathrm{C}_{6} \mathrm{H}_{4}$<smiles>CC1CCC(C)CC1</smiles><smiles>CC1CCC(C)CC1</smiles>

$1.45^{\mathrm{b}}$

3

1

Naphthalene<smiles>c1ccc2c(c1)CCCC2</smiles><smiles>C[C@@]12CCCC[C@]1(C)CCC2</smiles>

$0.001^{\mathrm{c}}$

5

1

$\underset{1}{\mathrm{C}_{6} \mathrm{H}_{6}}+\underset{1}{1,4-\left(\mathrm{CH}_{3}\right)_{2} \mathrm{C}_{6} \mathrm{H}_{4}}$

$\mathrm{C}_{6} \mathrm{H}_{12}+1,4$ - Dimethylcyclohexane ${ }^{\mathrm{d}}$

$6.80^{e}, 1.42^{f}$ 97

3

(3: 1 trans: cis)

${ }^{2} \mathrm{P}_{\mathrm{H}_{2}}=190 \mathrm{psi}$; [arene] $=11 \mathrm{M}$ (neat), temp $=90^{\circ} \mathrm{C}$. ${ }^{\mathrm{b}}$ Turnover frequency independent of conversion.

${ }^{\mathrm{c}}$ Turnover frequency at $5 \%$ substrate conversion; solvent $=$ pentane. ${ }^{\mathrm{d}}$ Product mixture at complete benzene consumption. ${ }^{e}$ Initial turnover frequency. ${ }^{\mathrm{f}}$ Turnover frequency at complete benzene consumption. 
Scheme I

Possible Scenario for $\operatorname{Th}\left(\eta^{3} \text {-allyl }\right)_{4} / \mathrm{DA}-$
Catalyzed Arene Hydrogenation

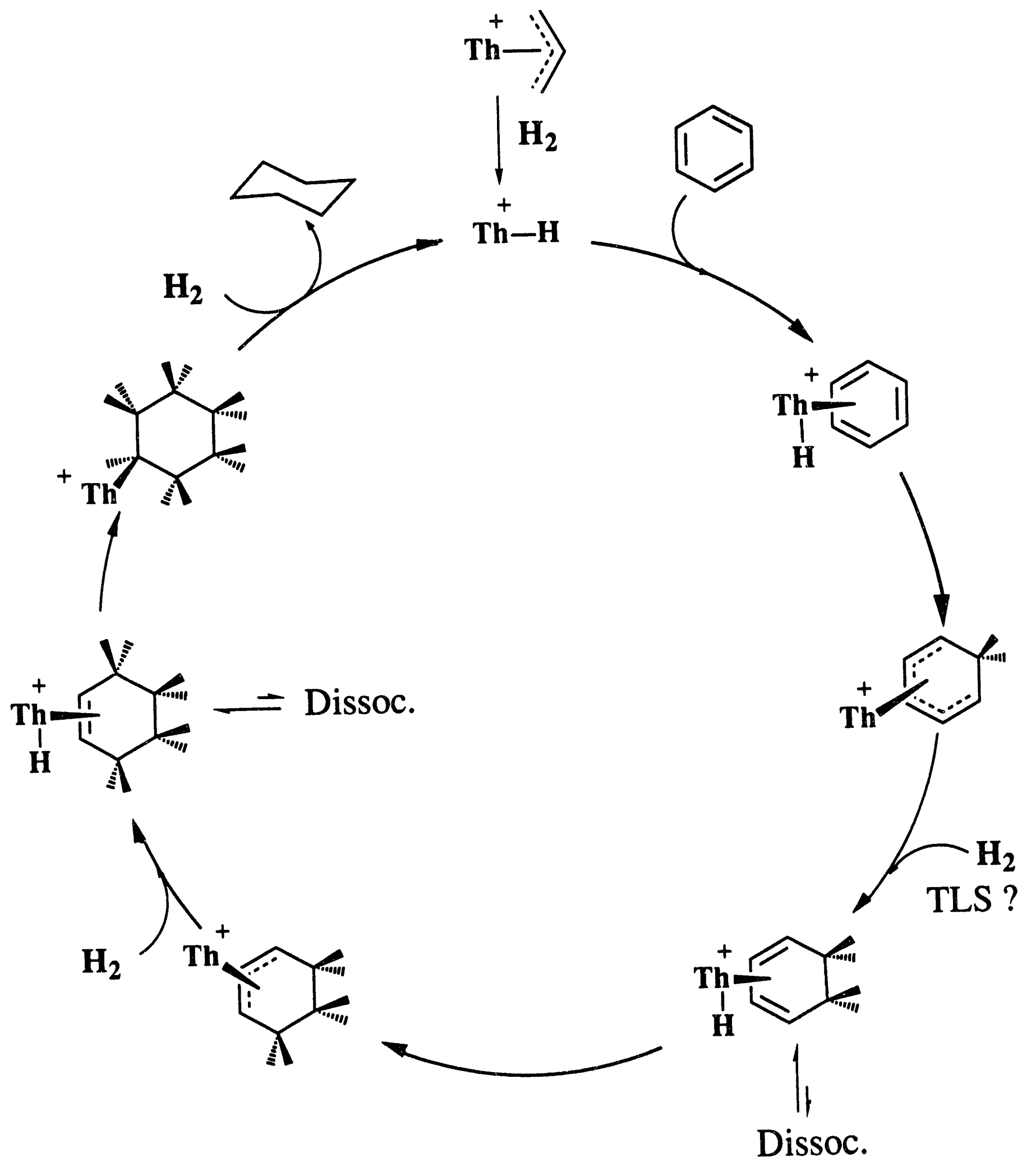


mixtures reveal that benzene is preferentially hydrogenated with almost complete exclusion of $p$-xylene $(\sim 97: 3)$, inferring that the benzene binding constant to the active sites is $\sim 6.7 \times$ that of $p$-xylene. It is possible to propose a mechanism for arene hydrogenation which involves single $\mathrm{Th}(\mathrm{IV})$ sites, inoperativity of oxidation addition/reductive elimination sequences, and which passes among established metal-ligand structures via precedented pathways. A working hypothesis is shown in Scheme I.

The adsorption of $\operatorname{Th}\left(\eta^{3} \text {-allyl }\right)_{4}$ on dehydroxylated alumina (DA) yields an active catalyst for the exchange of alkane and cycloalkane $\mathrm{C}-\mathrm{H}$ bonds with $\mathrm{D}_{2}$. Thus, at $90^{\circ} \mathrm{C}, 50$ psi $\mathrm{D}_{2}, \mathrm{C}-\mathrm{H} \rightarrow \mathrm{C}-\mathrm{D}$ turnover frequencies as high as $1285 \mathrm{~h}^{-1}$ are measured. Relative C-H reactivities fall in the order: primary $>$ secondary $>$ tertiary, and less sterically hindered $>$ more sterically hindered. Cis $-1,2$ and cis - 1,4 - dimethylcyclohexane undergo concurrent isomerization to cis + trans mixtures under the reaction conditions (Table II). Poisoning experiments indicate a maximum of $8 \pm 1 \%$ of the $\operatorname{Th}\left(\eta^{3}\right.$ allyl) ${ }_{4} / \mathrm{DA}$ sites are catalytically significant, while EPR and XPS indicate low-valent $(<4)$ Th oxidation states are below the detection limit. The mechanism is discussed in terms of reversible electrophilic "four-center" activation processes in which dimethylcyclohexane isomerization occurs via $\beta-H$ elimination/readdition, and in which the active sites probably bear sterically significant nonhydridic ancillary ligation. A proposed scenario is shown in Scheme 11 .

B. Homogeneous Model Studies

1. Advanced Lewis Acid Co-Catalysts

In efforts to design organo-Lewis acids which would model the abstractive role that we have postulated for alumoxane co-catalysts (eq.(1)), we found that $\mathrm{B}\left(\mathrm{C}_{6} \mathrm{~F}_{5}\right)_{3}$ is both a structural and

$$
\begin{aligned}
\mathrm{L}_{\mathbf{n}} \mathrm{MR}_{2} & +\mathrm{A} \rightarrow \mathrm{L}_{\mathrm{n}} \mathrm{MR}^{+} \mathrm{RA}^{-} \\
\mathrm{L}_{\mathrm{n}} & =\text { ancillary ligands } \\
\mathrm{A} & =\text { Lewis acid }
\end{aligned}
$$

functional model (eq. (2)). High olefin polymerization activities are observed and the first detailed 


\section{Table I. Kinetic and Product Structure/Label Distribution Data for Th( (ク-allyl)a/ DA - Catalyzed Alkane C.H $\rightarrow$ C.D Functionalization"}

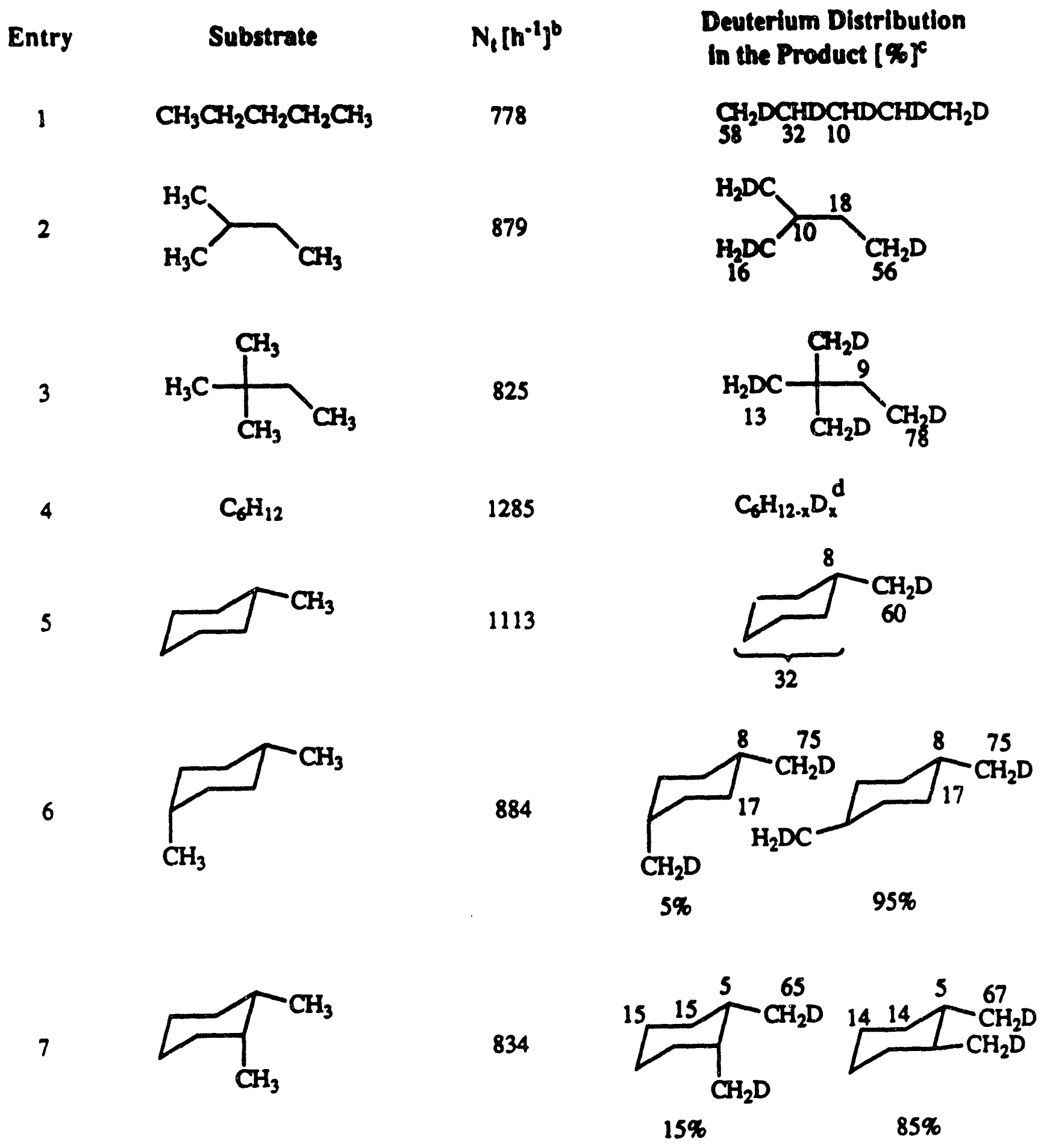

'At $90^{\circ} \mathrm{C}, 50$ psi $D_{2}$; Th : substrate $=1: 1,000 ; D_{2}:$ substrate $=100: 1$.

bSubstrate $\mathrm{C}-\mathrm{H}$ bonds converted/catalyst active site $\mathrm{h}$.

From ${ }^{13} \mathrm{C}\left({ }^{1} \mathrm{H}\right),{ }^{13} \mathrm{C}$, and ${ }^{2} \mathrm{H}\left({ }^{1} \mathrm{H}\right)$ NMR spectroscopy. Estimated uncertainty, $\pm 5 \%$.

${ }^{d}$ Different isotopomers cannot be resolved by NMR spectroscopy. 
Scheme II. Possible Scenario for the Th( $\eta^{3}-$ allyl), / DA Catalyzed C-H Activation and Isomerization af Alkanes

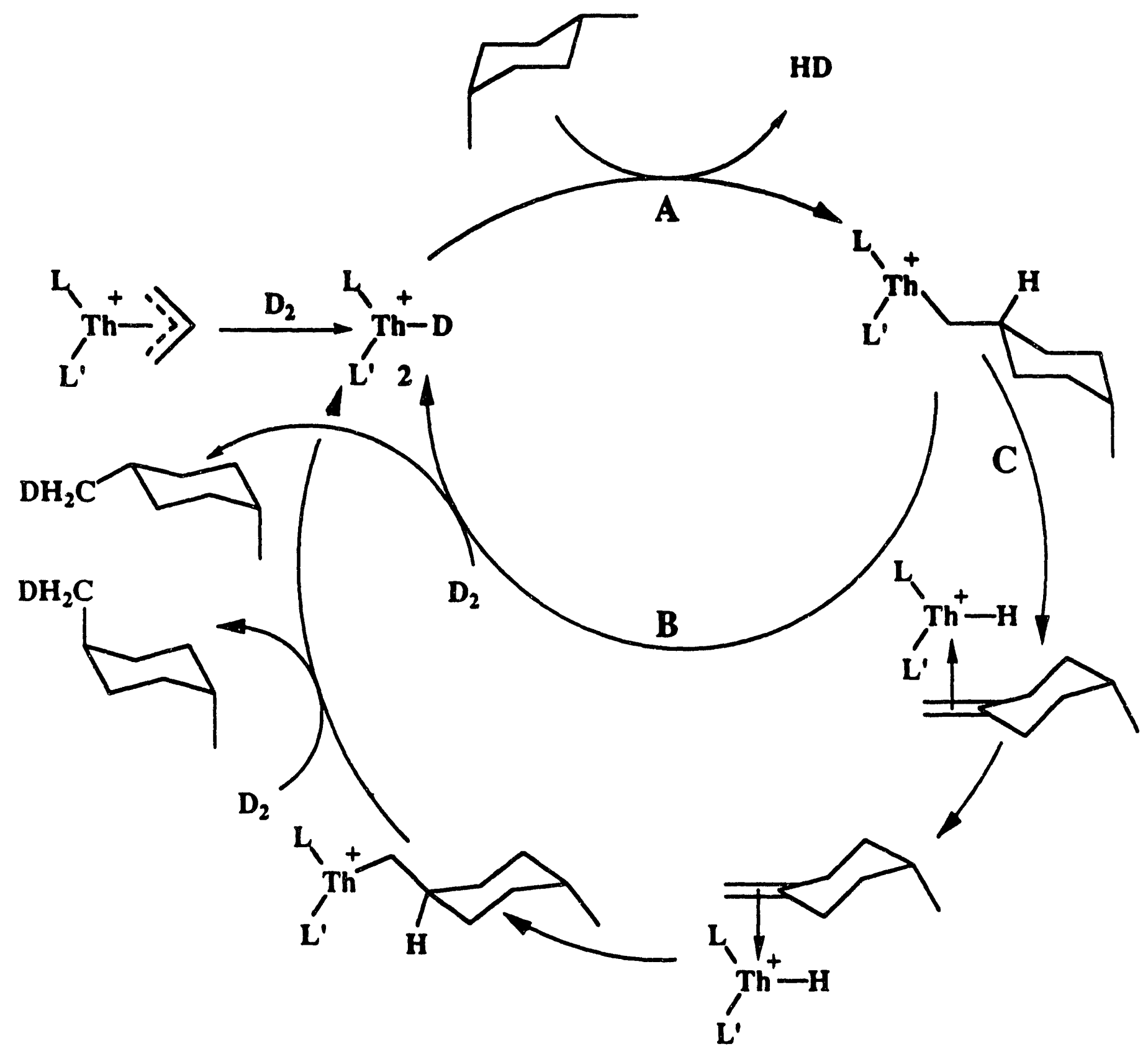




$$
\begin{aligned}
\mathrm{L}_{2} \mathrm{Zr}_{r}\left(\mathrm{CH}_{3}\right)_{2}+\mathrm{B}\left(\mathrm{C}_{6} \mathrm{~F}_{5}\right)_{3} \stackrel{\mathrm{C}_{6} \mathrm{H}_{6} \text { or pentane }}{\longrightarrow} & \mathrm{L}_{2} \mathrm{ZrCH}_{3}^{+} \mathrm{CH}_{3} \mathrm{~B}\left(\mathrm{C}_{6} \mathrm{~F}_{5}\right)_{3} \\
\mathrm{~L} & =\eta^{5}-\mathrm{C}_{5} \mathrm{H}_{5} \\
\mathrm{~L} & =\eta^{5}-1,2-\left(\mathrm{CH}_{3}\right)_{2} \mathrm{C}_{5} \mathrm{H}_{3} \\
\mathrm{~L} & =\eta^{5}-\left(\mathrm{CH}_{3}\right)_{5} \mathrm{C}_{5}
\end{aligned}
$$

structural data obtained (e.g., Figure 1, $\mathrm{Cp}^{\prime}=\eta^{5}-\mathrm{Me}_{5} \mathrm{C}_{5}$ ). Such structures are the first structural, spectroscopic, and functional models of MAO-activated metallocene polymerization catalysts. The $\mathrm{B}\left(\mathrm{C}_{6} \mathrm{~F}_{5}\right)_{3}$ cocatalyst also led to the first cationic zirconocene hydrides, heretofore elusive species that must be key components in $\beta-\mathrm{H}$ chain transfer and hydrogenolytic molecular weight control. The first

Hydrogenolysis and Abstractive Routes to Cationic Hydrides

$$
\begin{aligned}
& {\left[\mathrm{Cp}_{2}^{\prime} \mathrm{ZrCH}_{3}\right]^{+}\left[\mathrm{CH}_{3} \mathrm{~B}\left(\mathrm{C}_{6} \mathrm{~F}_{5}\right)_{3}\right]^{-} \underset{-\mathrm{CH}_{4}}{\stackrel{\mathrm{H}_{2} / \text { pentane }}{\longrightarrow}}\left[\mathrm{Cr}_{2}^{\prime} \mathrm{ZrH}\right]^{+}\left[\mathrm{CH}_{3} \mathrm{~B}\left(\mathrm{C}_{6} \mathrm{~F}_{5}\right)_{3}\right]^{-}}
\end{aligned}
$$

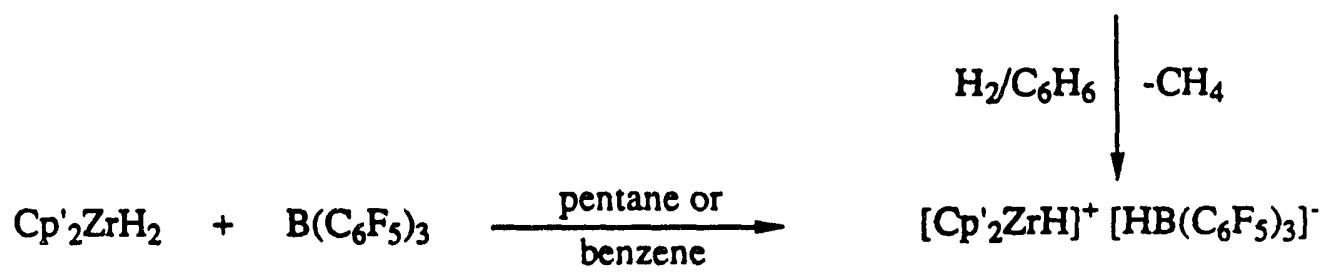

crystal structure data (Figure 2) for a zirconocene hydride were also obtained. It revealed the surprising absence of a Zr-H-B bridge.

$A$ number of other $\mathrm{Zr}$ and $\mathrm{Hf}$ alkyl systems were subjected to reaction with $B\left(C_{6} F_{8}\right)_{3}$ (e.g., $\left.\mathrm{Cp}^{\prime} \mathrm{ZrMe} \mathrm{M}_{3} ; \mathrm{Zr}_{(}\left(\mathrm{CH}_{2} \mathrm{Ph}\right)_{4}\right)$ with the goal being to produce new, more coordinatively unsaturated cations. Although ethylene polymerization catalysts could be generated in situ at low temperatures, the predominant reaction mode was redistribution (e.g., eq. (3)), which presumably proceeds via an

$$
\mathrm{L}_{2} \mathrm{M}-\mathrm{R}+\mathrm{B}\left(\mathrm{C}_{6} \mathrm{~F}_{5}\right)_{3} \rightarrow \mathrm{L}_{\mathrm{D}} \mathrm{M}-\mathrm{C}_{6} \mathrm{~F}_{5}+\mathrm{RB}\left(\mathrm{C}_{6} \mathrm{~F}_{5}\right)_{2}
$$

electrophilic group 4 cation.

Two complementary efforts were also made to synthesize new organo-Lewis acids: i) modified alumoxanes, ii)new boranes. In the former area, we successfully prepared a very potent alumoxane- 
FIGURE 1

\section{CRYSTAL STRUCTURE of $\mathrm{Cp}^{\prime}{ }_{2} \mathrm{ZrCH}_{3}{ }^{+} \mathrm{CH}_{3} \mathrm{~B}\left(\mathrm{C}_{6} \mathrm{~F}_{5}\right)_{3}{ }^{-}$}

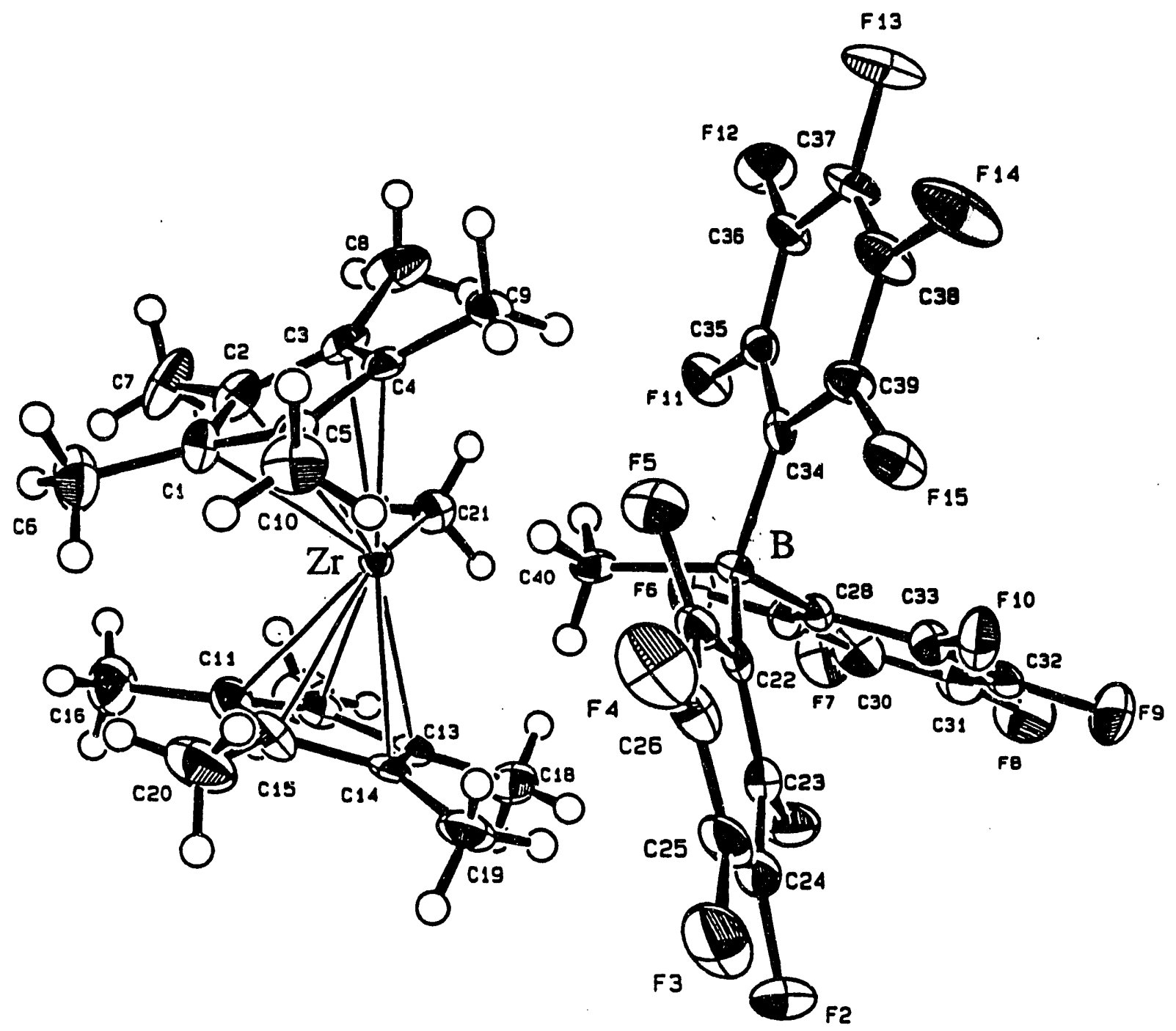

$\mathrm{Zr}-\mathrm{C} 21 \quad 2.223(6) \AA$

$\mathrm{Zr}-\mathrm{C} 40 \quad 2.640(7)$

B - C40 1.66(1)

$\mathrm{Zr}-\mathrm{C} 40-\mathrm{B}$
$\mathrm{Zr}-\mathrm{H} 40 \mathrm{~A} \quad 2.507$

$\mathrm{Zr}-\mathrm{H} 40 \mathrm{~B} \quad 2.432$

$\mathrm{Zr}-\mathrm{H} 40 \mathrm{C} \quad 2.526$ 


\section{FIGURE 2}

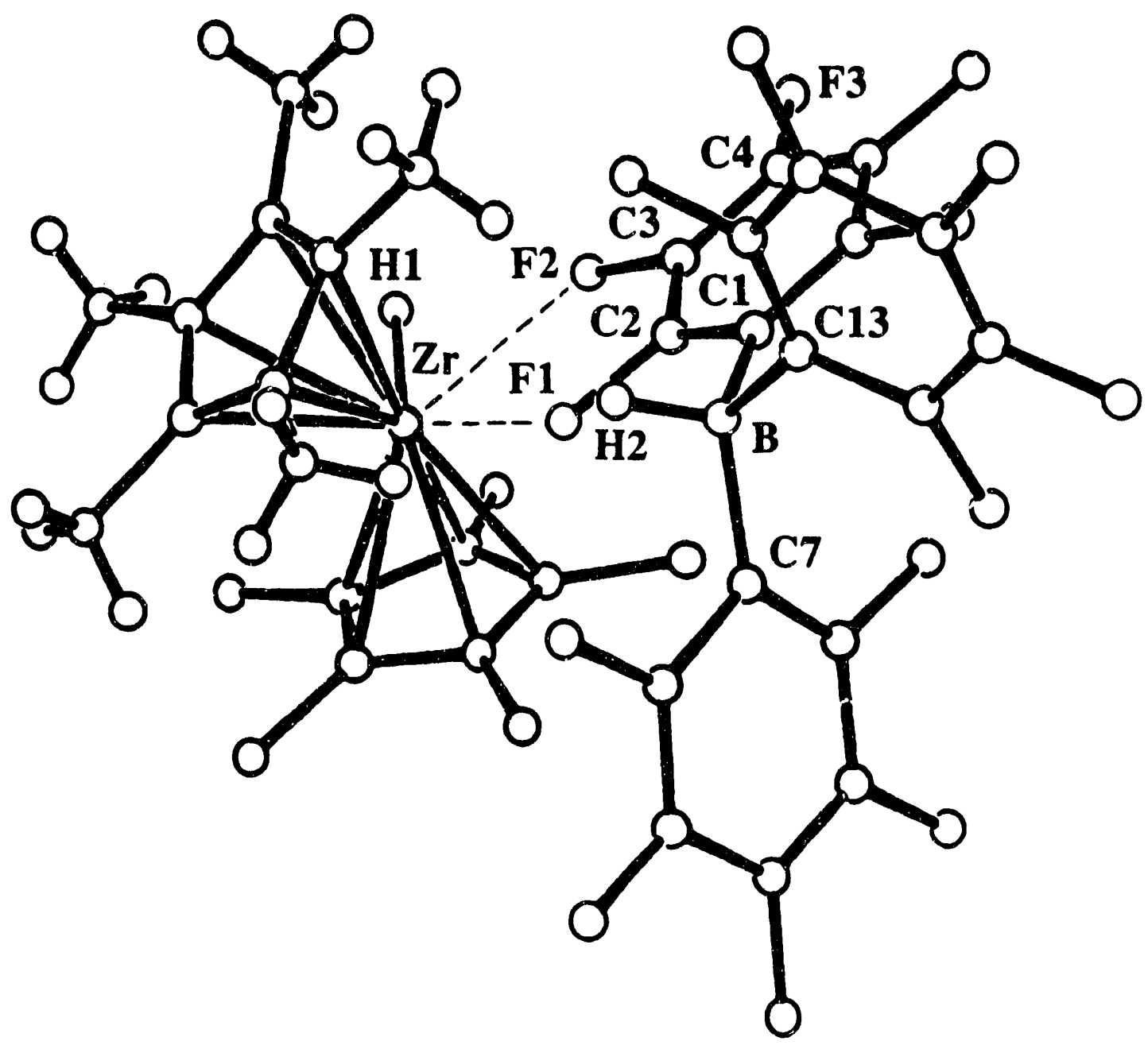

Molecular structure of $\left[\mathrm{Cp}_{2}^{\prime} \mathrm{ZrH}\right]^{+}\left[\mathrm{HB}\left(\mathrm{C}_{6} \mathrm{~F}_{5}\right)_{3}\right]^{-}$. Important bond distances $[\AA]$ and angles $\left[^{\circ}\right]$ are as follows: $\mathrm{Zr}-\mathrm{H} 1=2.00(5), \mathrm{Zr}-\mathrm{H} 2=4.87$ (5), $\mathrm{Zr}-\mathrm{F} 1=2.416(3), \mathrm{Zr}-\mathrm{F} 2=2.534$ (3), $\mathrm{B}-\mathrm{H} 2=1.06$ (6), $\mathrm{H} 2-\mathrm{B}-\mathrm{C} 1=104$ (3), H2-B-C7 = 109 (3), H2-B-C13 = 105 (3), C1-B-C7 = 112.9 (4), C1-B-C13 = 111.9 (4), $\mathrm{H} 1-\mathrm{Zr}-\mathrm{F} 1=128(1), \mathrm{H} 1-\mathrm{Zr}-\mathrm{F} 2=65$ (1). Only one of two $\left(\mathrm{CH}_{3}\right)_{5} \mathrm{C}_{5}$ orientations is shown for the disordered ring. 
like co-catalyst (AAO, "advanced alumoxane") using $\mathrm{C}_{6} \mathrm{~F}_{5} \mathrm{OH}$ (eq. (4) or (5)). We tentatively assign

$$
\begin{gathered}
\mathrm{MAO}+\mathrm{C}_{6} \mathrm{~F}_{5} \mathrm{OH} \rightarrow \text { AAO } \\
\left(\mathrm{C}_{6} \mathrm{~F}_{5} \mathrm{OAlMe}_{2}\right)_{2}+\mathrm{H}_{2} \mathrm{O} \rightarrow \mathrm{AAO}
\end{gathered}
$$

a structure such as $\mathbf{A}$ to AAO. Presumably by virtue of the very strongly electron - withdrawing

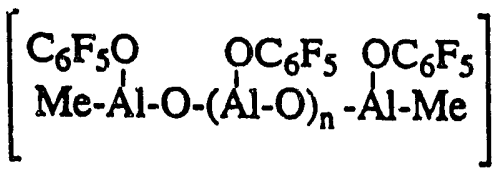

AAO

( $n=2-3$, as estimated from elemental analysis results. Has also been characterized by solution ${ }^{19} \mathrm{~F}$ and solid state ${ }^{27} \mathrm{Al}$ NMR spectroscopy)

substituents and steric bulk, very active zirconocene - based olefin polymerization systems can be produced at very low Al:Zr ratios (unlike MAO).

The other tack has involved the synthesis of new borane organo-Lewis acids, which has turned out to be very challenging. The route to trifluomethyl - substituted aryl boranes yielded cnly partial borane arylation (eq. (6)). Efforts to product cationic polymerization catalysts with B were

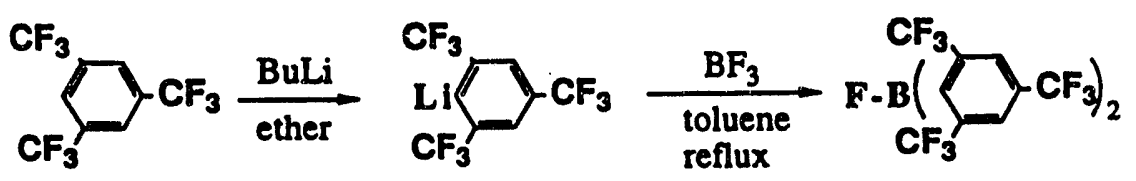

unsuccessful but highly informative (eqs. (7), (8)).

$$
\begin{gathered}
\mathrm{Cp}_{\mathrm{Z}} \mathrm{ZrMe}_{2}+\mathrm{B} \rightarrow \mathrm{Cp}_{2} \mathrm{Zr}(\mathrm{F}) \mathrm{Me}+\mathrm{MeB}_{6}\left[\mathrm{C}_{6} \mathrm{H}_{2}\left(\mathrm{CF}_{3}\right)\right]_{2} \\
\mathrm{C} \\
\mathrm{Cp}_{2} \mathrm{ZrMe}_{2}+\mathrm{C} \rightarrow \text { No Reaction }
\end{gathered}
$$


Greater success has been obtained with routes to difunctional chelating organo-Lewis acids (eqs. (9), (10), $\left.\mathrm{R}=\mathrm{C}\left(\mathrm{CH}_{3}\right)_{3}\right)$. Purification and catalysis studies are presently in progress.

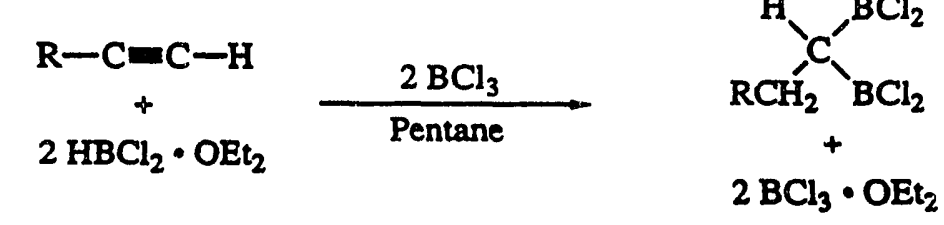<smiles>[R]CC(Br)(Br)C(Br)(Br)Br</smiles>

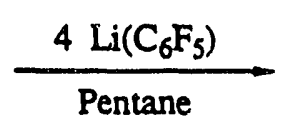<smiles>[R2]C(Br)C(Br)(c1ccccc1)c1ccccc1</smiles>

\section{$4 \mathrm{LiCl}$}

2. B-Alkyl Elimination Processes in Homogeneous Ziegler Catalysis.

Processes by which $\beta$-alkyl groups are transferred to the metal center have long been debated as possible chain termination sequences in Ziegler-Natta polymerization catalysis (eq. (11), where $\mathrm{P}$ = growing polymer chain). Understanding what factors switch this behavior "on" or "off" would be a

$$
\mathrm{M}-\mathrm{CH}_{2} \stackrel{\mathrm{CHP}_{3}}{\longrightarrow} \mathrm{M}-\mathrm{CH}_{3}+\mathrm{CH}_{2}=\mathrm{CHP}
$$

great asset in polymerization catalyst design. Our curiosity was especially stimulated by the observations shown below using stoichiometrically well-defined zirconocene catalysts (here $\mathrm{Cp}^{\prime}=\eta^{5}$ $\mathrm{Me}_{5} \mathrm{C}_{5}$ ). The formation of polypropylene with a vinyliso-propyl microstructure is particularly

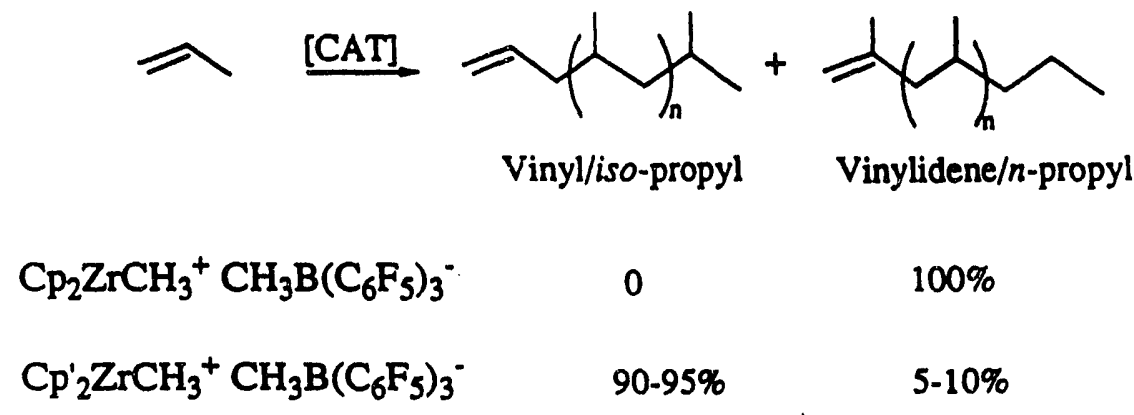

intriguing. As shown below, a vinylidene/ $n$-propyl microstructure is best explained by the well-known B-H elimination pathway, which has a great deal of precedent. A priori, two very different mechanisms must be invoked to explain the formation of polypropylene with a vinyViso-propyl 
\&.

Vinylidene/n-propyli:

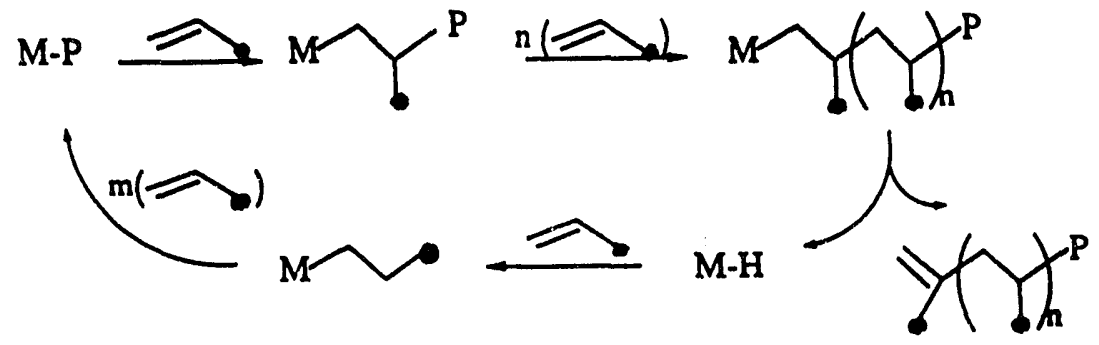

microstructure. Both $\beta$-methyl elimination and allylic C-H activation have firm precedent in

b. B-Me elimination mechanism.

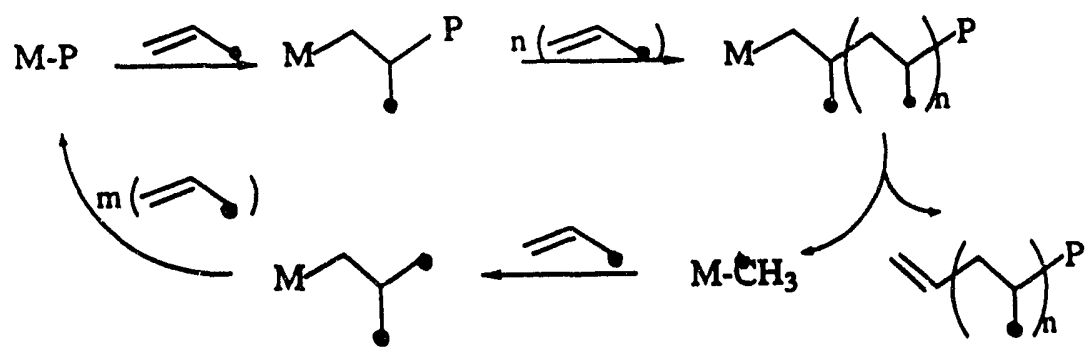

c. Allylic activation mechanism.

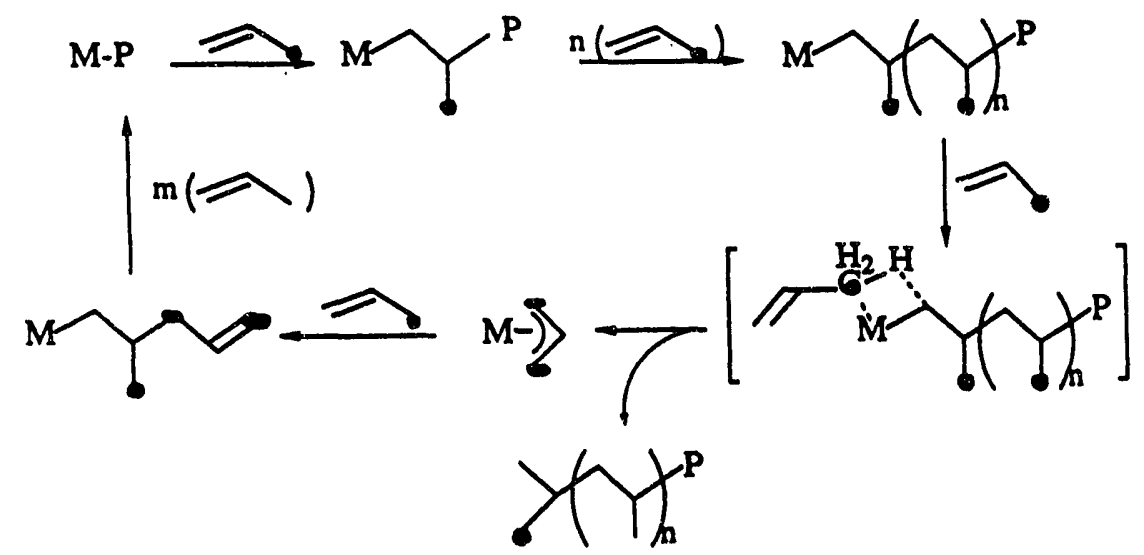

organolanthanide chemistry.

To rigorously differentiate between these mechanisms, experiments were carried out with ${ }^{13} \mathrm{C}$. labelled propylene $\left(\mathrm{CH}_{2}=\mathrm{CH}\left({ }^{13} \mathrm{CH}_{3}\right)\right)$. The dark spots in the above three mechanistic scenarios trace the expected label positions in the product. NMR experiments allow us to rigorously verify the $\beta$ - 
methyl elimination pathway and to completely rule out the allylic C-H activation mechanism. A minor role for a 2-1 insertion pathway (eq.(12)) was also identified.

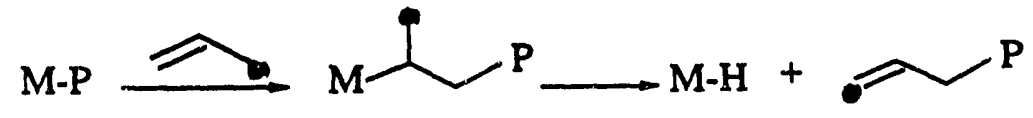

We feel that the significance of these results goes beyond understanding what catalyst structures defeat chain growth. Equally important is using this information to invent new propagation pathways (see below).

3. Ring-Opening Ziegler Polymerization (ROZP).

In principle, it might be possible to couple $\beta$-alkyl elimination in strained cyclic monomers with olefin insertion processes to provide a new type of polymerization pathway (eq. (13)). The product

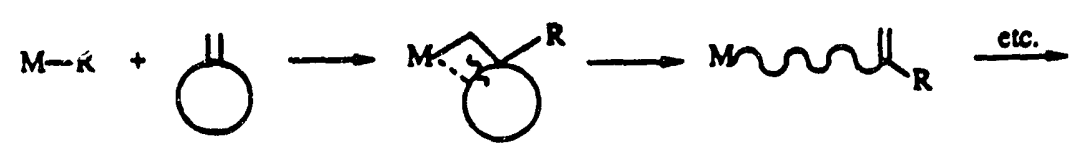

would be an unusual, exomethylene - functionalized homo - or copolymer. Using commercially available methylenecyclobutane (D) as a model monomer, we find that our cationic zirconocene catalysts induce rapid, regiospecific ring-openning polymerization (Figures 3A,B; Scheme IIIA) to<smiles>C=C1CC(C)C1</smiles>

produce high molecular weight homopolymers (Table III). Furthermore, addition of ethylene to the polymerization reaction produces high molecular weight copolymers (Table III), which are essentially exomethylene - functionalized polythylenes. A rigorous test of our mechanistic thinking is provided by ${ }^{13} \mathrm{C}$ labelling studies which verify that the methylenecyclobutane ring-openning occurs at the $\mathrm{C} 2$ C3/C4 - C5 junctions as predicted for $\beta$-alkyl transfer (Scheme IIIB). This result can be readily assayed by ${ }^{1} \mathrm{H}$ NMR (Figure $3 C$ ). This new polymerization mechanism offers efficient routes to a wealth of heretofore inaccessible, functionalized polyolefins 


\section{FIGURE CAPTIONS}

Figure 3. A. ${ }^{1} \mathrm{H}$ NMR $\left(400 \mathrm{MHz}, \mathrm{C}_{6} \mathrm{D}_{6}, 25^{\circ} \mathrm{C}\right)$ of polymethylenecyclobutane produced by a $\left(1,2-\mathrm{Me}_{2} \mathrm{C}_{5} \mathrm{H}_{3}\right)_{2} \mathrm{ZrMe}^{+} \mathrm{MeB}\left(\mathrm{C}_{6} \mathrm{~F}_{5}\right)_{3}{ }^{*}$ catalyst (entry 2, Table I).

B. ${ }^{13} \mathrm{C}$ NMR (100 $\left.\mathrm{MHz}, \mathrm{C}_{6} \mathrm{D}_{6}, 25^{\circ} \mathrm{C}\right)$ of the polymethylenecyclobutane sample shown in Figure 3A.

C. ${ }^{1} \mathrm{H}$ NMR $\left(600 \mathrm{MHz}\right.$, biphenyl- $\left.\mathrm{d}_{10}, 140^{\circ} \mathrm{C}\right)$ of the copolymer formed from methylenecyclobutane and ${ }^{13} \mathrm{CH}_{2}={ }^{13} \mathrm{CH}_{2}$ (>YS* ${ }^{13} \mathrm{C} ;-1.0$ : 100 monomer ratio) with a $\left(1,2-\mathrm{Me}_{2} \mathrm{C}_{5} \mathrm{H}_{3}\right)_{2} \mathrm{ZrMe}^{+} \mathrm{MeB}\left(\mathrm{C}_{6} \mathrm{~F}_{5}\right)_{3}^{-}$catalyst. The peak a:b:b' area ratios are 1.0:1.0:1.0 \pm 5\% (Scheme IB predicts 1.0:1.0:1.0). 
A.
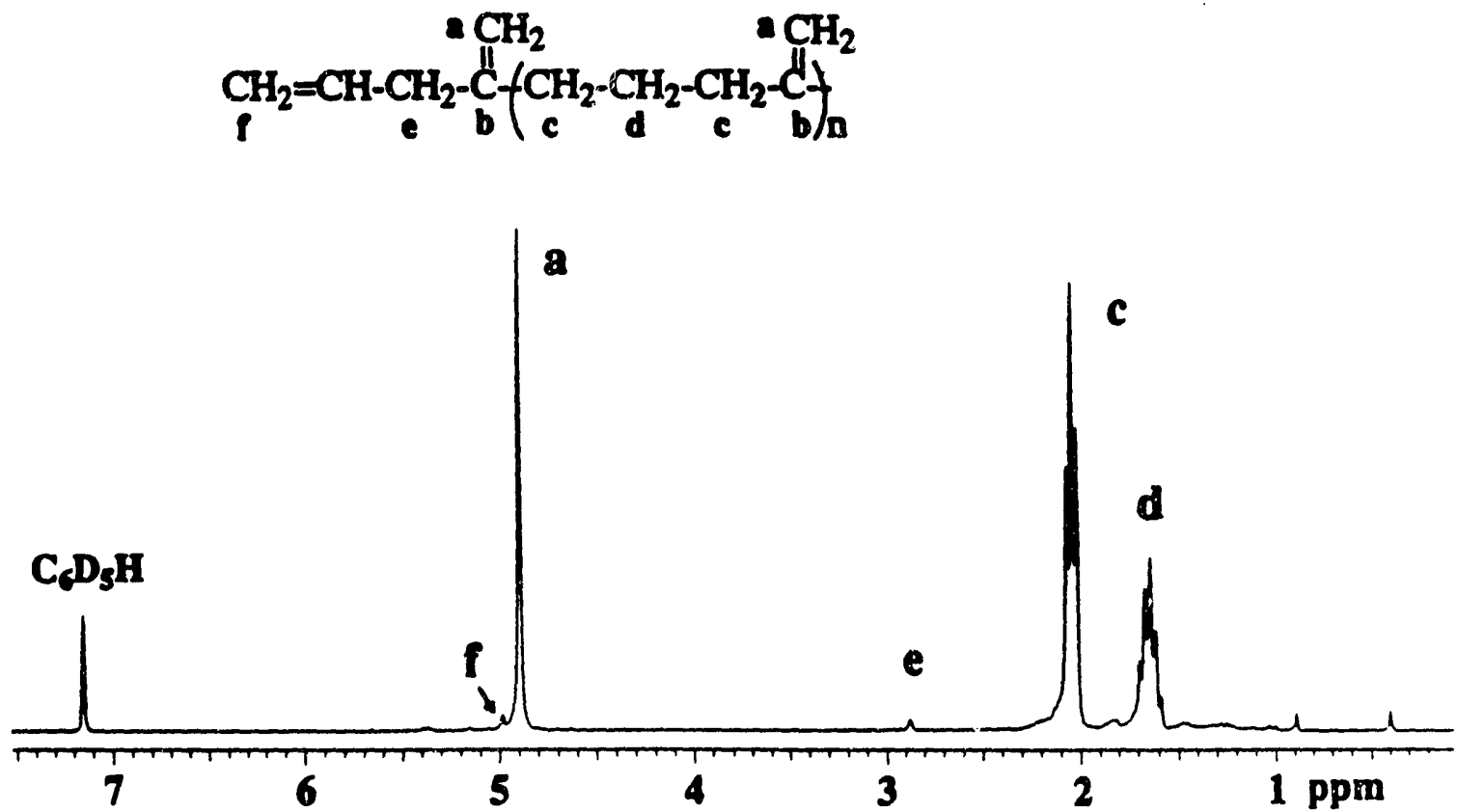

B.

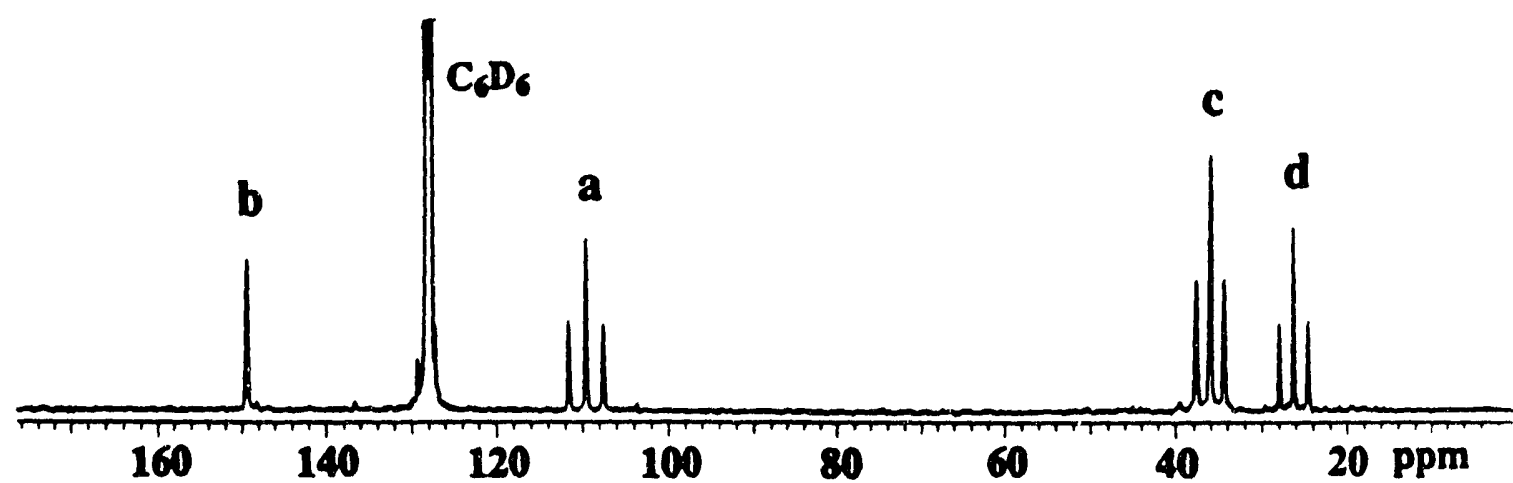

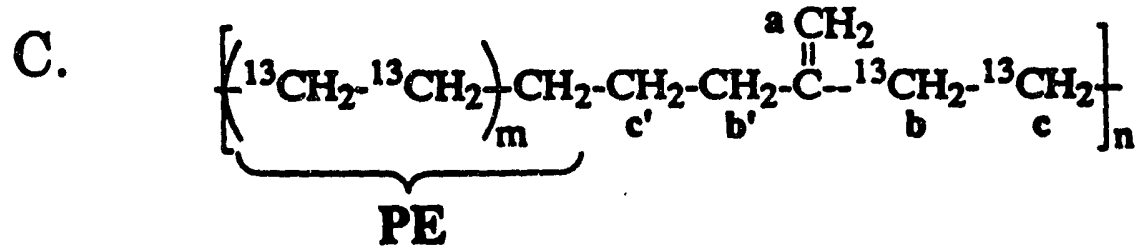

Biphenyi-dxo

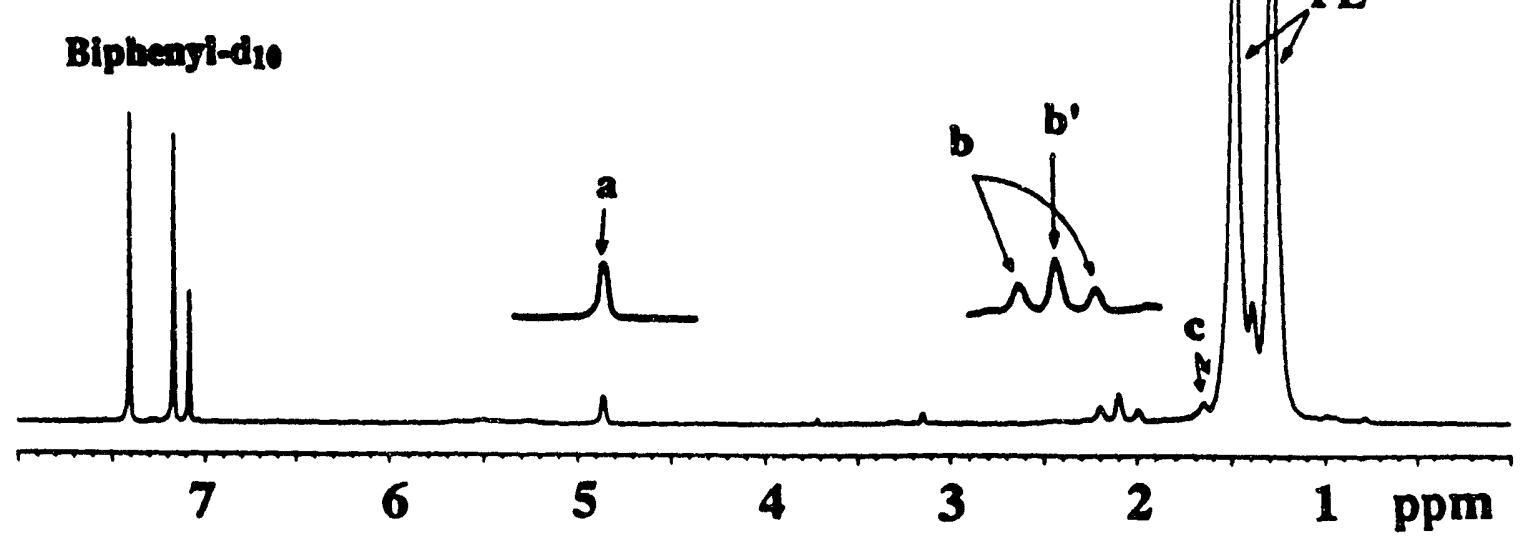


Scheme III. Proposed Mechanisms for the Cationic Zirconocene-

Catalyzed Ring-Opening Polymerization of Methylenecyclobutane and Copolymerization with Ethylene

A. Homopolymerization of Methylenecyclobutane<smiles>[Z7]CC1([Y])CC(=C)C1</smiles><smiles>[R]C(=C)CCC(C)(C)[Z7]CC</smiles><smiles>[H][Z7]C(C)CC</smiles><smiles>[R]C(=C)CCC(C)(C)C(=C)CC=C</smiles>

B. Copolymerization with Ethylene

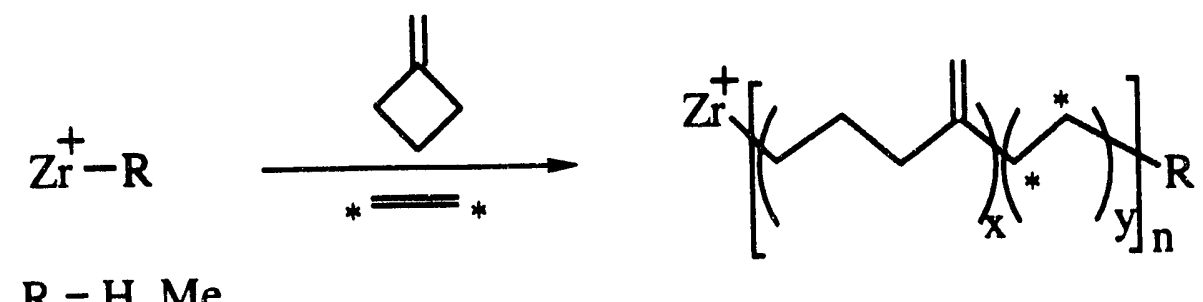

$\mathrm{R}=\mathrm{H}, \mathrm{Me}$ 


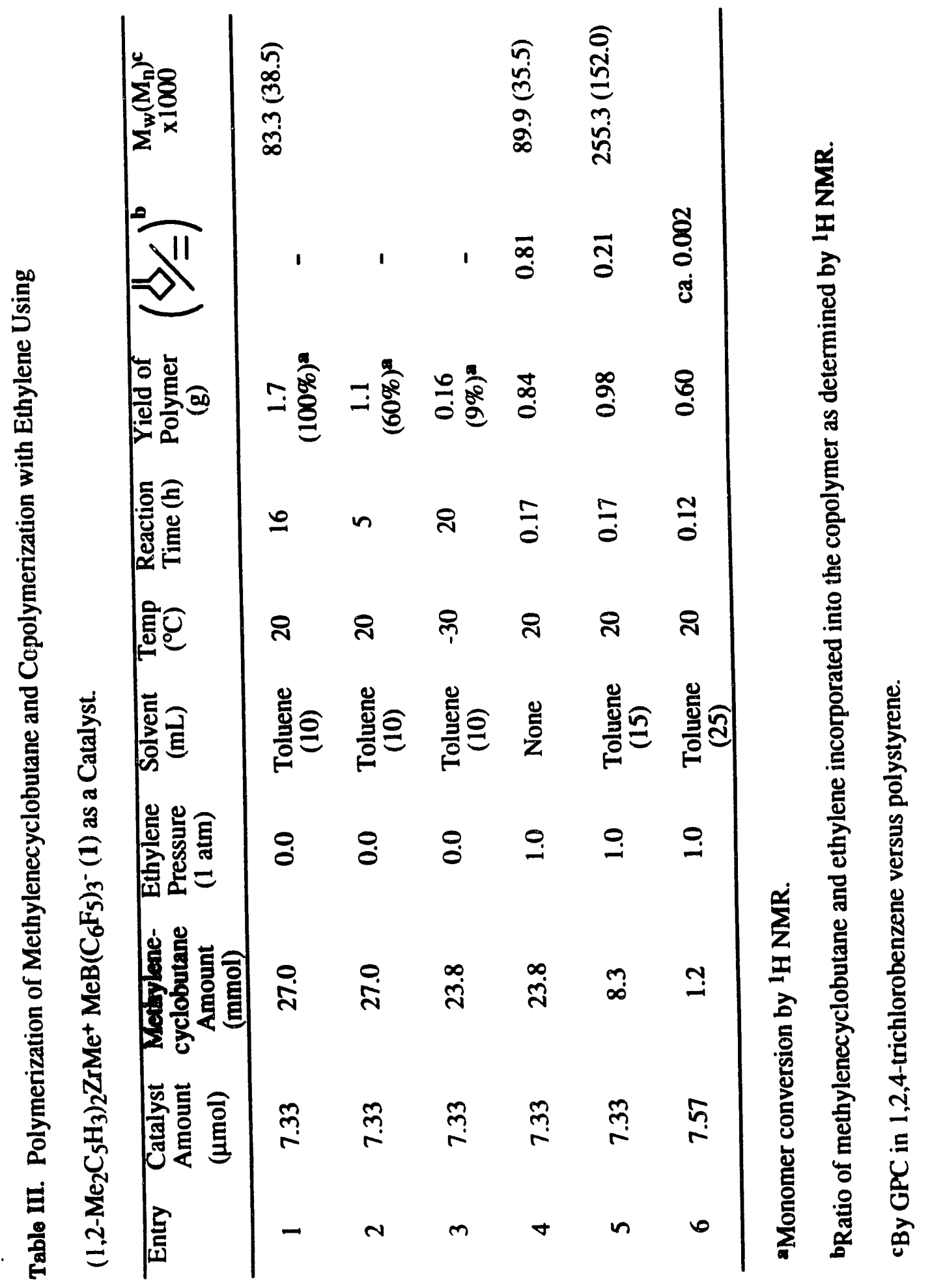


C. Chiral Ligand Systems for Stereoregular Olefin Polymerization

The recent advances that have been made in stereoregular olefin polymerization have largely depended upon $\mathrm{C}_{2}$ - symmetric ancillary ligands $(\mathbf{E})$. The synthesis of such catalysts involves tedious ligand syntheses, nontrivial separation of undesired meso isomers (F), and subsequent derivatizations/-

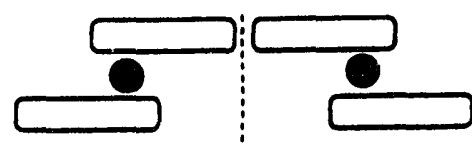

$\mathbf{E}$

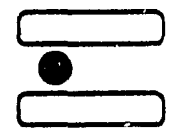

$\mathbf{F}$
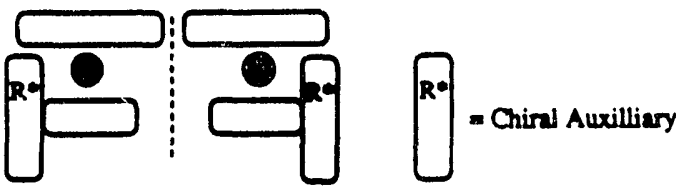

G

separations if individual catalysts antipodes are desired. We have devised ring-bridged $C_{1}-$ symmetric "template" ligands (G; Scheme IV) which cannot form meso structures and in which individual catalysts antipodes are accessible by simple crystallization. As can be seen in Table IV, zirconium complexes of these ligands, when activated by the appropriate co-catalysts, are capable of polymerizing propylene with activities and stereoregularities comparable to those many of the best $\mathrm{C}_{2}-$ symmetric systems (especially entries 4,9, and 10). Equally important is the strong sensitivity of catalyst activity as well as product molecular weight and isotacticity to the nature of the co-catalyst (Table IV). We attribute these effects to the strong cation-anion interactions that must occur in the coordination spheres of these metallocene cations. These effects were never previously explored in such depth and convey important guidelines for stereoregular catalyst design. 


\section{Scheme IV. Synthesis of Chiral Zirconium Complexes ${ }^{\mathrm{a}}$}

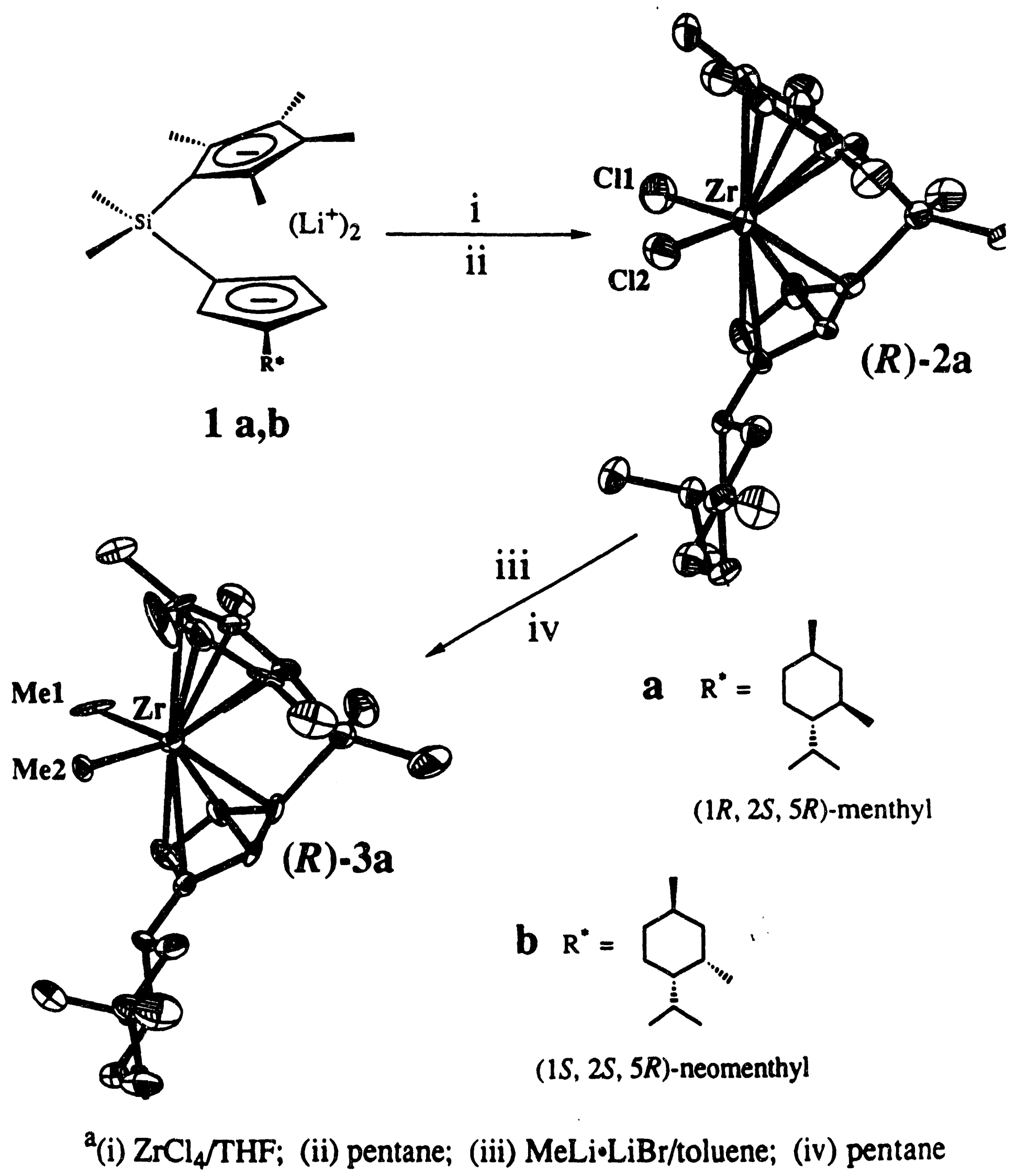




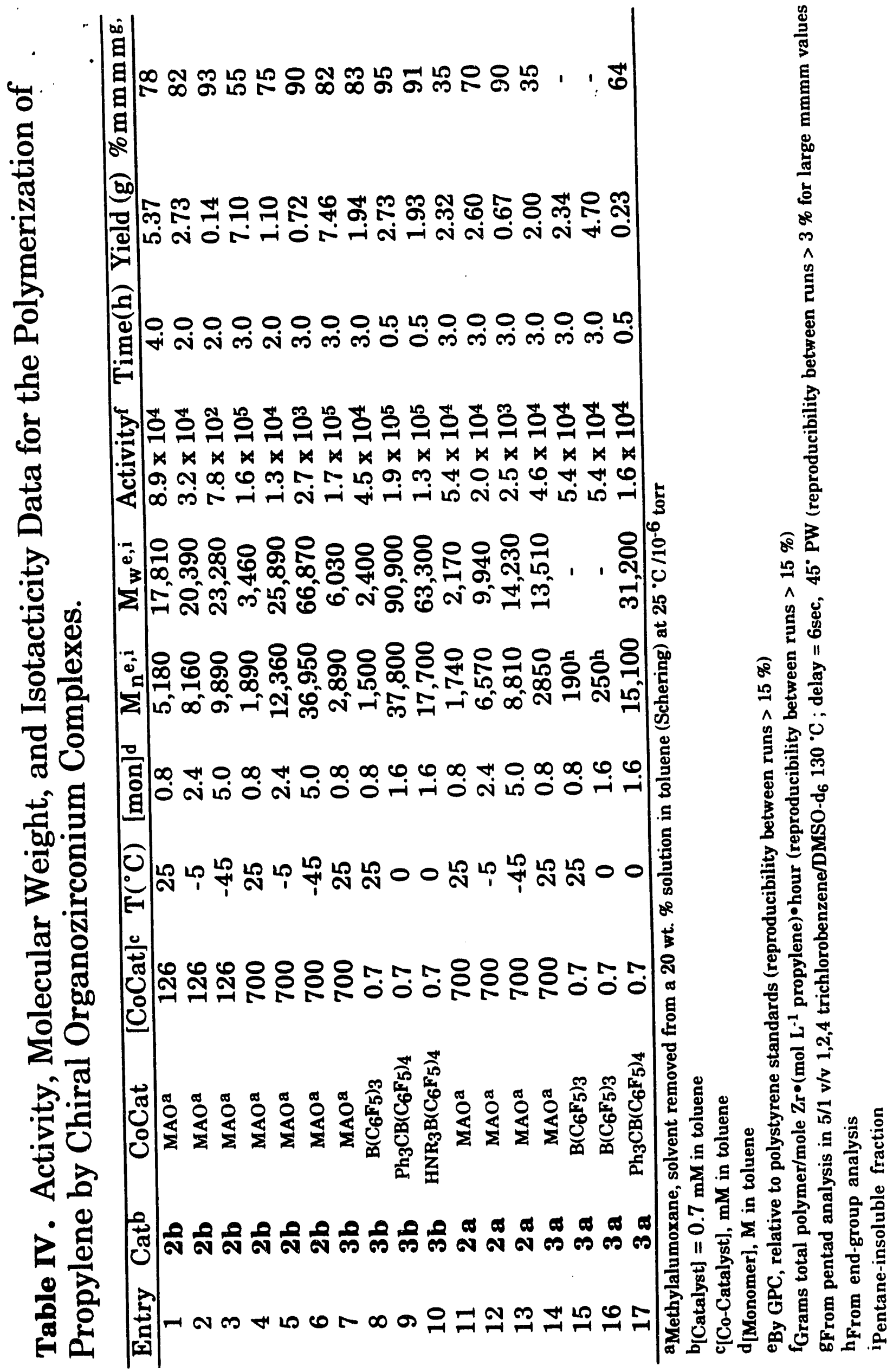



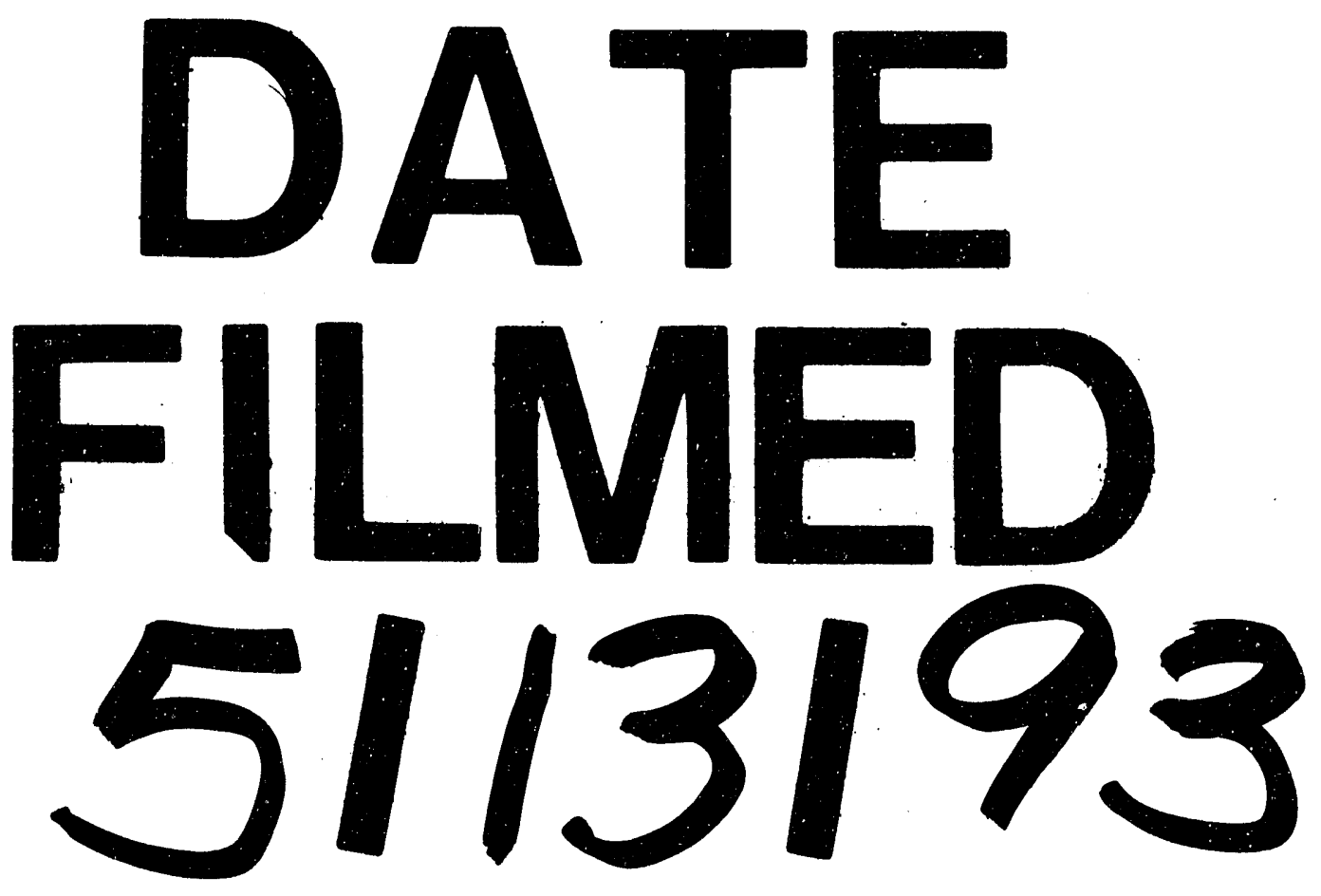
